\title{
$\mathrm{Cu}$ 계 및 $\mathrm{Ni}$ 계 비정질 합금 분말을 이용한 비정질기지 복합재의 제조 및 특성
}

\author{
김택수* · 이진규 · 김휘준 · 배정찬 \\ 한국생산기술연구원 벌크비정질 및 나노소재개발사업단
}

\section{Synthesis and Properties of Amorphous Matrix Composites using Cu-based/Ni-based Amorphous Powders}

\author{
Taek-Soo Kim*, Jin-Kyu Lee, Hwi-Jun Kim and Jung-Chan Bae \\ R\&D Division for Bulk Amorphous and Nano Materials, Korea Institute of Industrial Technology, \\ 994-32 Techno-park Songdo, Dongchun-Dong, Incheon, 406-130, Korea
}

(Received October 26, 2005; Accepted December 1, 2005)

\begin{abstract}
This work is to present a new synthesis of metallic glass (MG)/metallic glass (MG) composites using gas atomization and spark plasma sintering (SPS) processes. The MG powders of $\mathrm{Cu}_{54} \mathrm{Ni}_{6} \mathrm{Zr}_{22} \mathrm{Ti}_{18}(\mathrm{CuA})$ and $\mathrm{Ni}_{59} \mathrm{Zr}_{15} \mathrm{Ti}_{13} \mathrm{Nb}_{7} \mathrm{Si}_{3} \mathrm{Sn}_{2} \mathrm{Al}_{1}$ (NiA) as atomized consist of fully amorphous phases and present a different thermal behavior; $T_{g}$ (glass transition temperature) and $T_{x}$ (crystallization temperature) are $716 \mathrm{~K}$ and $765 \mathrm{~K}$ for the Cu base powder, but $836 \mathrm{~K}$ and $890 \mathrm{~K}$ for the Ni base ones, respectively. SPS process was used to consolidate the mixture of each amorphous powder, being $\mathrm{CuA} / 10 \% \mathrm{NiA}$ and $\mathrm{NiA} / 10 \% \mathrm{CuA}$ in weight. The resultant phases were $\mathrm{Cu}$ crystalline dispersed NiA matrix composites as well as NiA phase dispersed $\mathrm{CuA}$ matrix composites, depending on the SPS temperatures. Effect of the second phases embedded in the MG matrix was discussed on the microstructure and mechanical properties.
\end{abstract}

Keywords : $\mathrm{Cu}$ - and Ni-based glass powders, Amorphous/amorphous Composites, Gas atomization, SPS, Glass forming ability

\section{1. 서 론}

벌크 비정질 합금은 초고강도 특성은 물론 내마모 성 및 내식성이 우수하여 차세대 소재로 많은 주목 을 받고 있으나, 상대적으로 낮은 인성에 기인하여 산업적 응용에 제한을 받고 있는 실정이다 ${ }^{1-4)}$. 이러한 단점을 보완하기 위하여 비정질 금속과 연성이 우수 한 결정질 금속간의 복합재료화가 시도되고 있다5). 대 표적인 비정질/결정질 복합재료 제조법으로 In-situ') 및 비정질 기지에 제2상을 첨가하는 Ex-situ법 ${ }^{7-8)}$ 을 들 수 있으나, 공정의 복잡성과 강도의 저하 등이 야기되 는 등 많은 어려움이 보고되고 있는 형편이다.

본 연구에서는 이와 같은 문제점을 극복하기 위한
새로운 방법 즉, 분말야금공정을 이용한 비정질/비정 질 복합재료의 제조를 제안하고 시도하였다. 이는 Insitu와 Ex-situ 두 가지 이상의 제조 공정을 조합한 것으로서, 하나의 비정질 기지에 열적특성이 상이한 또 하나의 비정질 합금을 제 2 상으로 첨가하였다. 즉, 결정화 온도가 다른 두 비정질 합금을 혼합 후 기지 재료의 $\Delta \mathrm{Tx}$ (과냉각액상영역) 구간에서 spark plasma sintering을 실시하였다. 이때, 저온 비정질이 강화상 인 경우 강화상의 결정화 및 분산이 이루어지고, 그 반대인 경우는 고온 고강도 비정질 입자가 강화상이 되도록 하였다. 한편, 이러한 신복합재료의 제조를 위 한 최적의 공정으로 분말야금공정을 이용하였는테, 이는 급속응고가 용이하면서 형상 및 크기의 제약이

*Corresponding Author : [Tel : +82-32-850-0409; E-mail : tskim@kitech.re.kr] 
없고 혼합 및 합금화가 매우 용이하기 때문이다 ${ }^{9-10)}$. 비정질/비정질 복합재료의 제조를 위해서 결정화 거 동이 서로 다른 $\mathrm{Cu}_{54} \mathrm{Ni}_{6} \mathrm{Zr}_{22} \mathrm{Ti}_{18}(\mathrm{CuA})$ 와 $\mathrm{Ni}_{59} \mathrm{Zr}_{15} \mathrm{Ti}_{13^{-}}$ $\mathrm{Nb}_{7} \mathrm{Si}_{3} \mathrm{Sn}_{2} \mathrm{Al}_{1}(\mathrm{NiA})$ 계 비정질 분말을 가스 분무공정을 이용하여 제조하였다. 각각의 비정질 분말을 $\mathrm{CuA}$ $10 \mathrm{NiA}$ 및 $\mathrm{NiA} / 10 \mathrm{CuA}$ 조성이 되도록 볼밀링 공정 을 이용하여 혼합한 후, 각각의 비정질 분말의 열적 특성 차이를 이용하여 spark plasma sintering (SPS)을 실시하였다. 이때 예상되는 성형체의 조직은 $\mathrm{Cu}$ 계 나노결정질상이 분산된 $\mathrm{Ni}$ 계 비정질 복합재와 $\mathrm{Ni}$ 계 비정질 합금 강화 $\mathrm{Cu}$ 계 비정질 복합재이다. 제 조된 복합재의 특성을 단일 비정질 소결체 $(\mathrm{CuA}$ 및 $\mathrm{NiA})$ 와 비교하고 본 공정의 가능성을 검토하였다.

\section{2. 실험방법}

$\mathrm{Cu}_{54} \mathrm{Ni}_{6} \mathrm{Zr}_{22} \mathrm{Ti}_{18}(\mathrm{CuA})$ 과 $\quad \mathrm{Ni}_{59} \mathrm{Zr}_{15} \mathrm{Ti}_{13} \mathrm{Nb}_{7} \mathrm{Si}_{3} \mathrm{Sn}_{2} \mathrm{Al}_{1}$ (NiA) 비정질 조성의 모합금을 제조하기 위해 순도 $99.9 \%$ 의 상업용 $\mathrm{Cu}, \mathrm{Ni}, \mathrm{Zr}, \mathrm{Ti}, \mathrm{Nb}, \mathrm{Si}, \mathrm{Sn}, \mathrm{Al}$ 합금소재를 $2 \times 10^{-4}$ torr로 유지되는 플라즈마 용해로. (Vacuum plasma arc melter:VPM)를 이용하여 각 각 제조하였다. 제조된 각각의 모합금은 $2 \mathrm{~mm}$ 용탕 공급노즐이 부착되어 있는 진공 가스분무기 $(\mathrm{Gas}$ atomizer)의 용해 챔버에서 재용해 후 가스 분무하였 다. 이때, 분무압력과 진공도는 각각 $8 \mathrm{MPa}$ 및 $4 \times$ $10^{-5}$ torr 이었다. 가스분무 후 분급된 $90 \mu \mathrm{m}$ 이하 의 $\mathrm{Cu}$ 계 및 $\mathrm{Ni}$ 계 비정질 분말을 무게비로 $\mathrm{NiA}-10$, $90 \mathrm{CuA}$ 로 칭량하여 3차원 혼합기(3-D Mixer)를 이용 하여 비정질 혼합 분말을 제조하였다.

먼저 비정질 분말의 소결특성을 확인하기 위해 단 일 $\mathrm{Cu}$ 계 및 $\mathrm{Ni}$ 계 비정질 분말을 직경 $20 \mathrm{~mm}$, 두께 $5 \mathrm{~mm}$ 크기의 디스크 형태의 WC-Co 몰드에 충진하 여 냉간성형 후 방전풀라즈마 소결(SPS)하였다. 또한 동일 조건으로 비정질 복합재를 제조하기 위해 혼합 된 비정질 분말을 두 비정질 분말의 열적 특성 차이 즉, 비정질 분말의 유리천이온도 $(\mathrm{Tg})$ 와 결정화온도 $(\mathrm{Tx})$ 사이의 과냉각액상영역 $(\Delta \mathrm{T}=\mathrm{Tx}-\mathrm{Tg})$ 온도구간)를 이용하여 $\mathrm{Cu}$ 계 비정질상이 분산된 $\mathrm{Ni}$ 계 기지 비정질 복합재 $(\mathrm{Ni} / 10 \mathrm{CuA})$ 와 $\mathrm{Ni}$ 계 비정질상이 분산된 $\mathrm{Cu}$ 계 비정질 복합재 $(\mathrm{CuA} / 10 \mathrm{NiA})$ 를 제조하였다. 이때 SPS 는 $\Delta \mathrm{T}$ 영역의 온도인 $860 \mathrm{~K}$ 와 $735 \mathrm{~K}$ 에서 각각 실시하 였다.
단일 $\mathrm{Cu}$ 계 및 $\mathrm{Ni}$ 계 비정질 소결체와 각각의 비정 질 복합재의 구조 및 열적특성은 $\mathrm{X}$ 선 회절분석기 (XRD, Philips 1729) 및 시차열분석기(DSC, PerkinElmer DSC7)을 이용하여 조사하였다. 분말의 형상 및 파단면은 주사전자현미경(SEM, JSM 5410), 미세 조직은 광학현미경(OM, Shimazu)을 이용하여 관찰 하였으며, 밀도는 아르키메녜스법을 이용한 전자비중 계로, 경도는 $500 \mathrm{gf}$ 의 하중으로 마이크로비커스 $(\mathrm{Hv}$, Akashi HM-124)로 측정하였다. 압축강도는 $2 \times 2 \times 4$ $\mathrm{mm}$ 의 시편을 만능시험기에 장착 후 측정하였으며 이 때 변형률은 $1 \times 10^{-4} / \mathrm{s}^{-1}$ 이었다.

\section{3. 실험결과 및 고찰}

\section{1. 가스 분무된 $\mathrm{Cu}$ 계 및 $\mathrm{Ni}$ 계 비정질 분말톡성}

그림 1 은 $\mathrm{CuA} / 10 \mathrm{NiA}$ 및 $\mathrm{NiA} / 10 \mathrm{CuA}$ 복합재료를 제조하기 위하여 선택한 가스분무 $\mathrm{Cu}_{54} \mathrm{Ni}_{6} \mathrm{Zr}_{22} \mathrm{Ti}_{18}$ $(\mathrm{CuA})$ 합금분말과 $\mathrm{Ni}_{59} \mathrm{Zr}_{15} \mathrm{Ti}_{13} \mathrm{Nb}_{7} \mathrm{Si}_{3} \mathrm{Sn}_{2} \mathrm{Al}_{1}(\mathrm{NiA})$ 합

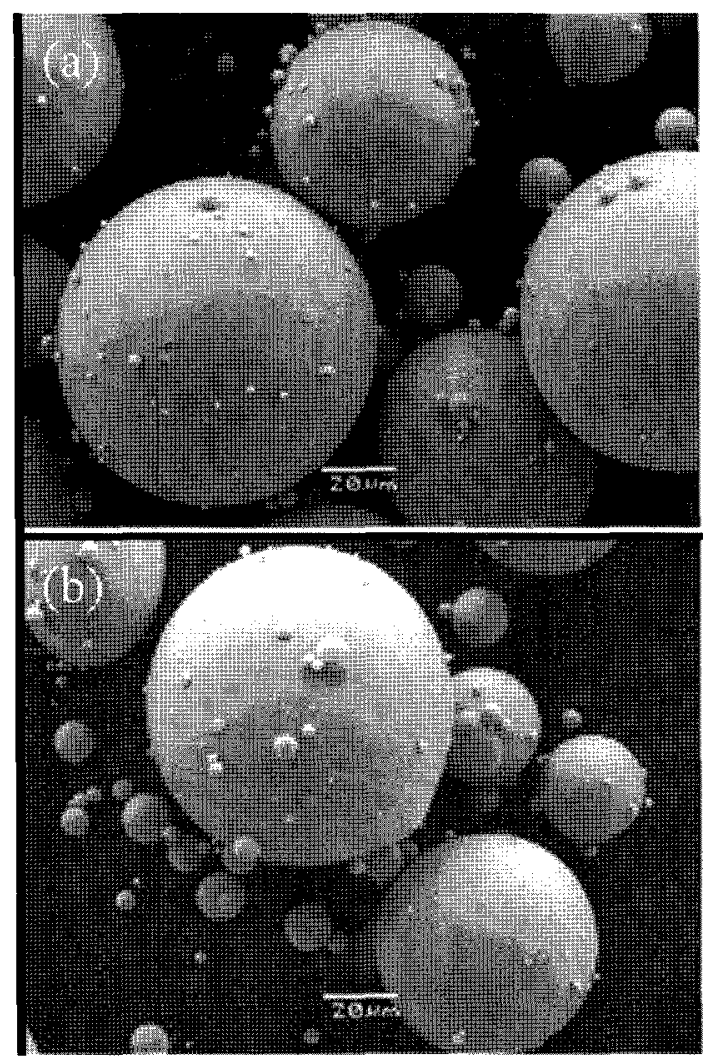

Fig. 1. Morphology of Cu-based (a) and Ni-based (a) amorphous powders. 
금분말의 형상을 관찰한 $\mathrm{SEM}$ 사진으로서, 대부분 $90 \mu \mathrm{m}$ 이하의 입도와 진구형을 나타내고 있다. 각각 의 합금분말을 XRD 및 DSC로 분석한 결과, 모두 비정질을 형성하고 있었다. 이때, 합금분말의 유리천 이온도 $(\mathrm{Tg})$, 결정화온도 $(\mathrm{Tx})$, 결정화엔탈피 $(\Delta \mathrm{H})$, 과냉 각액상영역 $(\Delta \mathrm{T}=\mathrm{Tx}-\mathrm{Tg})$ 은 $\mathrm{CuA}$ 의 경우 각각 $712 \mathrm{~K}$, $765 \mathrm{~K}, 65.1 \mathrm{~K} / \mathrm{g}, 55 \mathrm{~K}$ 이었고, $\mathrm{NiA}$ 의 경우 각각 $836 \mathrm{~K}$, $890 \mathrm{~K}, 44.9 \mathrm{~K} / \mathrm{g}, 54 \mathrm{~K}$ 이었다.

\section{2. 단일 $\mathrm{Cu}$ 계 및 $\mathrm{N}$ 계 비정질 소결체와 $\mathrm{Cu}$ 계} 및 $\mathrm{Ni}$ 계 비정질 복합재의 특성

그림 2(a-d)는 SPS를 이용하여 성형한 $\mathrm{CuA}(\mathrm{a})$, $\mathrm{NiA}(\mathrm{b})$ 단일계 성형체와 $\mathrm{CuA} / 10 \mathrm{NiA}(\mathrm{c}), \mathrm{NiA} / 10 \mathrm{CuA}$ (d) 비정질/비정질 복합재의 미세조직으로서, 전반적 으로 기공이 존재하지 않은 건전한 소결체가 제조되 었음을 알 수 있다. 상의 분포가 관찰되지 않는 두 단일계 성형체에 비해, $\mathrm{CuA}$ 를 $10 \%$ 첨가한 $\mathrm{Ni}$ 계 복
합재 (c) 및 $10 \% \mathrm{NiA}$ 가 첨가된 $\mathrm{Cu}$ 계 비정질 기지 복합재의 경우 (d)에는 제 2상이 기지상속에 분포되 어 있음을 명확히 확인할 수 있다. 그러나, 비정질 기지 속에 분산된 제 2상의 형상은 서로 달라서, (d) 의 경우에는 제 2상인 $\mathrm{Cu}$ 비정질의 형상이 기지와 복잡한 계면을 이루고 있는데 반해, (c)의 경우에는 $\mathrm{Ni}$ 계 비정질 분말형상이 변하지 않고 구형을 그대로 유지한 채 $\mathrm{Ni}$ 계 분말이 제 2상으로 분포되어 있다. 이는 SPS가 기지상의 $\Delta \mathrm{T}$ 영역 각각의 비정질의 초 소성 영역-에서 이루어지기 때문이다. 즉, 후자의 경 우 기지 $(\mathrm{CuA})$ 의 $\Delta \mathrm{T}$ 영역 내 온도인 $737 \mathrm{~K}$ 가 $\mathrm{NiA}$ 의 $\Delta \mathrm{T}$ 영역인 $836 \mathrm{~K} \sim 890 \mathrm{~K}$ 보다 낮아서, 기지의 소 결은 완료될 수 있었으나, 제 2상 분말인 $\mathrm{Ni}$ 은 소결 이 수반되지 않은 것이다. 반대로 전자의 경우는 기 지가 $\mathrm{Ni}$ 계 이므로, $\mathrm{NiA}$ 의 초소성 거동 온도인 $860 \mathrm{~K}$ 에서 기지분말과 제 2상 분말의 소결이 동시에 이루어질 수 있을 것이다. 단지 SPS 온도가 $\mathrm{CuA}$ 의

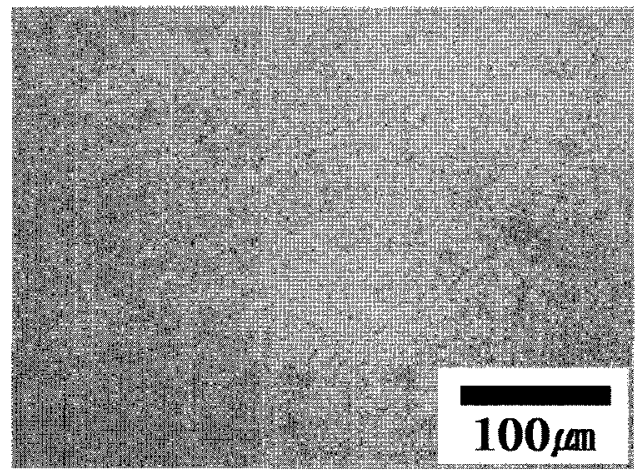

(a)

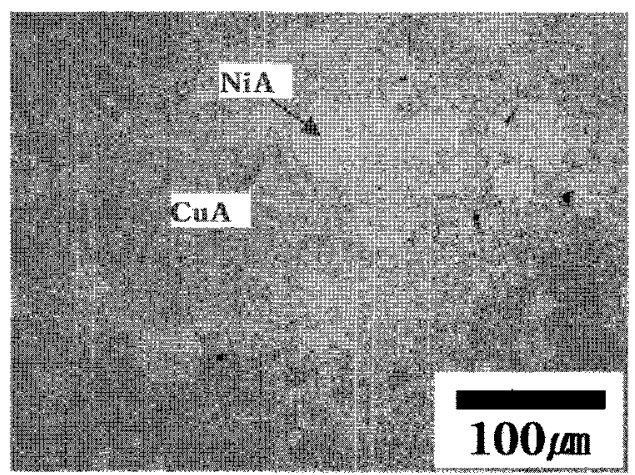

(c)

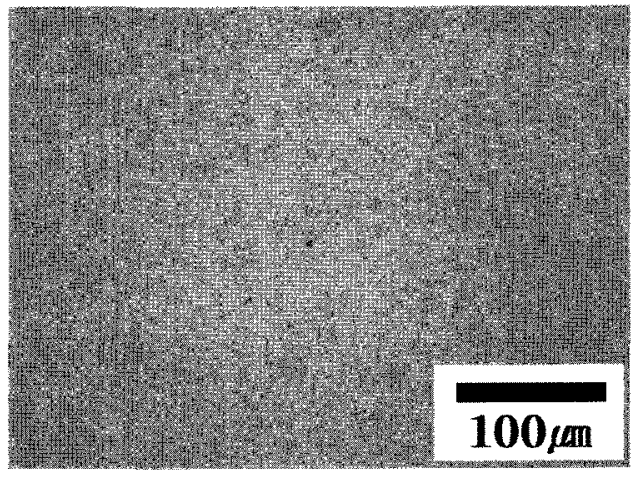

(b)

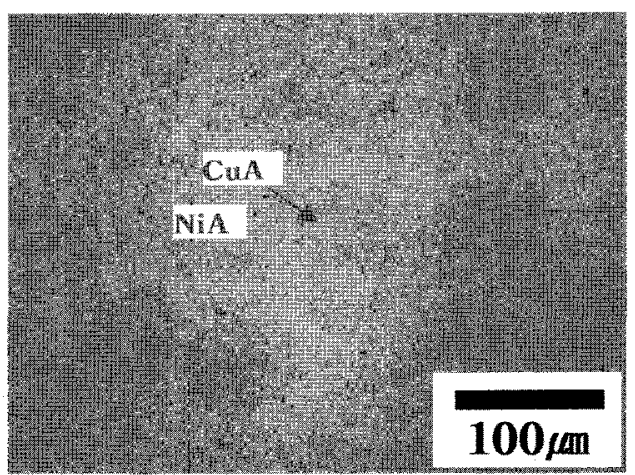

(d)

Fig. 2. Microstructure of SPSed monolithic MG of CuA (a) and NiA (b), and MG matrix composites of CuA/10NiA (b) and $\mathrm{NiA} / 10 \mathrm{CuA}$ (d). 
$\mathrm{Tx}$ 영역을 상회하므로 제 2상의 결정화가 예상된다.

그림 3(a)는 $737 \mathrm{~K}$ 에서 소결한 $\mathrm{CuA}$ 와 $\mathrm{CuA} / 10 \mathrm{NiA}$ 복합재의 $\mathrm{DSC}$ 곡선으로서, 단일 $\mathrm{Cu}$ 계 비정질 소결 체인 경우, 비정질 분말과 유사한 열적거동을 나타내 고 있어서 SPS 후에도 결정화가 수반되지 않았음을 알 수 있다. $\mathrm{CuA} / 10 \mathrm{NiA}$ 의 복합재의 경우, $\mathrm{CuA}$ 뿐만 아니라 $\mathrm{NiA}$ (점원으로 표시)에 관련한 피크가 동시에 검출됨으로 보아, 그림 2에서 설명한 바와 같이 $737 \mathrm{~K}$ 에서 $\mathrm{CuA}$ 는 성형이 이루어젔으며 $\mathrm{NiA}$ 는 성형 에 기여하지 못하고 $\mathrm{Cu}$ 비정질기지의 강화상(비정질) 으로 분포되고 있음을 알 수 있다. 한편, 단일재화 복합재의 $\mathrm{CuA}$ 관련 피크를 비교하여 보면, 후자의 열적특성 (유리리천이온도, 결정화온도, 발열량 등)이 발열량이 전자에 비해 약간 감소한 것을 확인할 수 있는뎨, 이는 $10 \% \mathrm{Ni}$ 계 비정질 분말의 첨가에 기인 한다.

한편 그림 $3(\mathrm{~b})$ 는 $860 \mathrm{~K}$ 에서 소결한 $\mathrm{NiA}$ 단일비정 질 소결체와 $\mathrm{Cu}$ 계를 $10 \%$ 첨가한 $\mathrm{NiA} / 10 \mathrm{CuA}$ 비정 질 복합재의 열분석 곡선으로서, 후자가 $10 \%$ 의 $\mathrm{CuA}$ 가 첨가되었음에도 불구하고 전자와 동일한 거동을 나타내고 있다. 이는 $\mathrm{CuA}$ 의 결정화 온도(약 $765 \mathrm{~K}$, 점원으로 표시) 이상인 $860 \mathrm{~K}$ 에서 $\mathrm{SPS}$ 를 실시하여, $\mathrm{CuA}$ 의 결정화를 수반한 $\mathrm{NiA}$ 의 비정질 성형을 의미 한다. 표 1은 비정질 복합재 및 단일 비정질 소결체 의 열분석 결과를 정리한 것이다.

복합재료의 조성 및 온도에 따른 상변화를 $\mathrm{XRD}$ 로 분석한 결과(그림 4)에서도, DSC 결과와 마찬가지로 단일 $\mathrm{CuA}$ 소결체와 $\mathrm{CuA} / 10 \mathrm{NiA}$ 복합 소결체 모두 동일한 비정질 할로패턴을 나타내고 있었다. 반면에 그림 4(b)의 $\mathrm{Cu}$ 졔를 $10 \%$ 첨가한 $\mathrm{Ni}$ 계 비정질 복합 재 $(\mathrm{NiA} / 10 \mathrm{CuA})$ 에서는 비정질 상을 형성하는 $\mathrm{NiA}$ 소결체와는 달리 비정질 할로 위에 매우 미세한 결 정질 피크가 형성 (점원으로 표시)되어 있음을 관찰 할 수 있었다. 이는 $\mathrm{DSC}($ 그림 $3 \mathrm{~b}$ )와 동일한 결과로

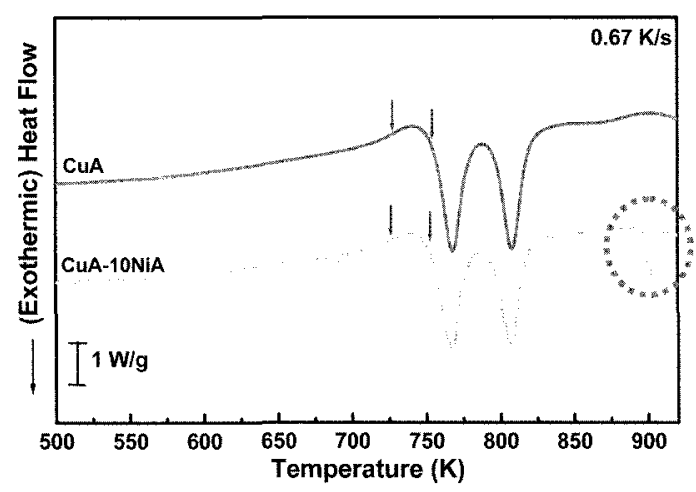

(a) $\mathrm{CuA}$ and $\mathrm{CuA} / 10 \mathrm{NiA}$

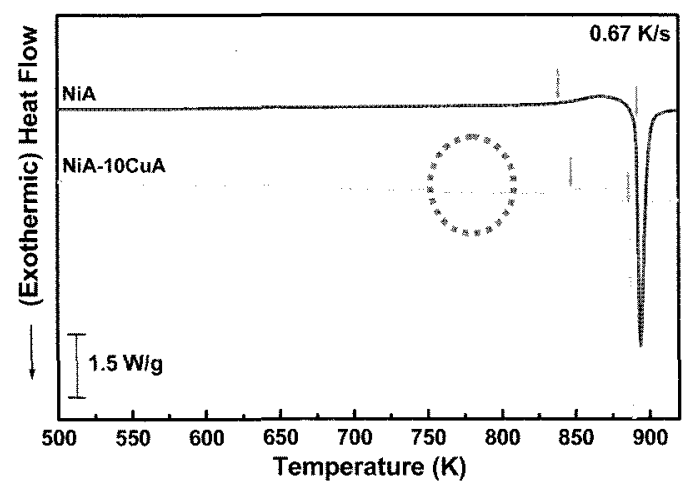

(b) NiA and NiA/10CuA

Fig. 3 DSC results of monolithic MG and MG matrix composites.

서, 상대적으로 $\mathrm{CuA}$ 의 결정화온도보다 높은 $\mathrm{SPS}$ 온 도에 의한 $\mathrm{CuA}$ 비정질상의 결정화에 기인한 것으로 판단된다.

표 2는 $\mathrm{CuA}, \mathrm{CuA} / 10 \mathrm{NiA}, \mathrm{NiA}$ 및 $\mathrm{NiA} / 10 \mathrm{CuA}$ 각각의 밀도와 상에 따른 경도 값이다. 밀도는 각각, $7.24,7.27,7.65$ 및 7.61 로서 이론밀도의 약 $99 \%$ 로 서 거의 진밀도를 보이고 있음을 알 수 있다. 경도는 $\mathrm{CuA}$ 및 $\mathrm{NiA}$ 모두 일반적인 비정질 고유의 경도-각 각 $560 \mathrm{Hv}$ 및 $734 \mathrm{Hv}$ 를 기록하고 있는 반면, $\mathrm{Cu}$ 나

Table 1. Thermal analysis of monolithic MG and MG matrix composites

\begin{tabular}{lllllll}
\hline \multirow{2}{*}{ Specimen } & \multicolumn{1}{c}{ Properties } & \multirow{2}{*}{$\mathrm{Tg}(\mathrm{K})$} & $\mathrm{Tx}(\mathrm{K})$ & \multicolumn{1}{c}{$\begin{array}{c}\mathrm{T}(=\mathrm{Tg}-\mathrm{Tx}) \\
(\mathrm{K})\end{array}$} & $\begin{array}{c}\Delta \mathrm{H} \\
(\mathrm{J} / \mathrm{g})\end{array}$ \\
\hline \multirow{2}{*}{ Cu-based } & Monolithic MG & 718.0 & 761.9 & 43.9 & 63.1 \\
& MG matrix composite & 716.4 & 760.5 & 44.1 & 56.8 \\
\hline \multirow{2}{*}{ Ni-based } & Monolithic MG & 839.0 & 891.0 & 44.7 & 52.0 \\
& MG matrix composite & 847.9 & 886.3 & 56.5 & 38.4 \\
\hline
\end{tabular}




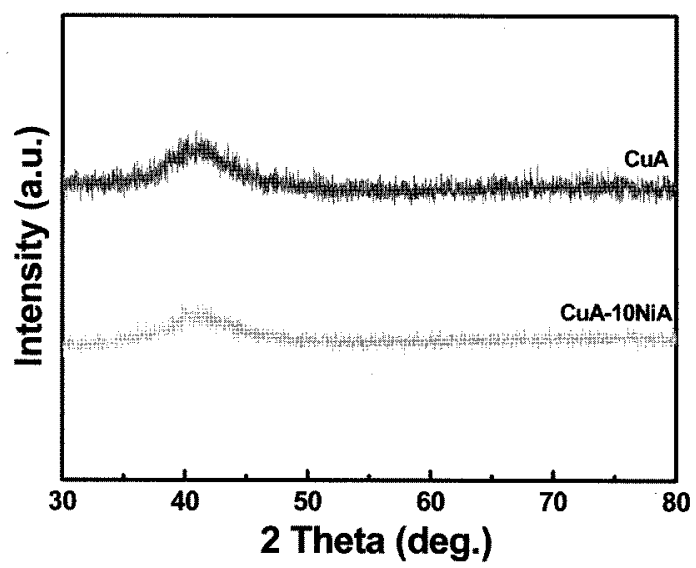

(a) $\mathrm{CuA}$ and $\mathrm{CuA} / 10 \mathrm{NiA}$

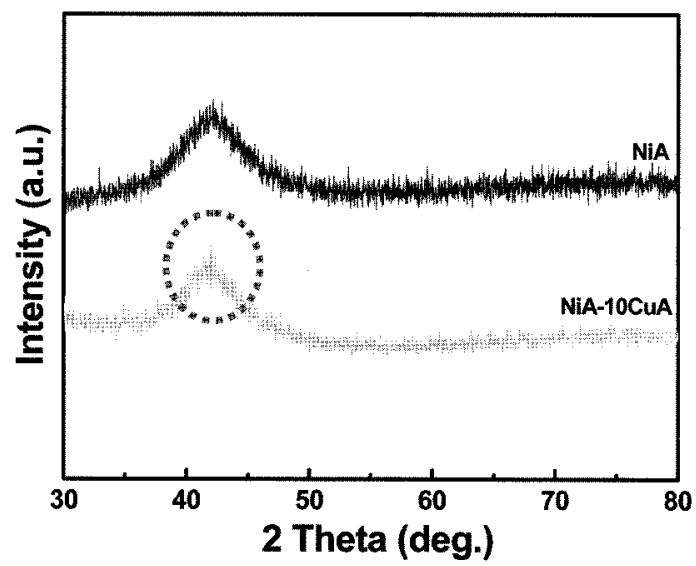

(b) $\mathrm{NiA}$ and $\mathrm{NiA} / 10 \mathrm{CuA}$

Fig. 4 XRD results of monolithic MG and MG matrix composites.

노결정이 분산된 $\mathrm{NiA} / 10 \mathrm{CuA}$ 복합재료의 경우 결정 질 $(\mathrm{Cu})$ 의 경도 $(785 \mathrm{Hv})$ 가 비정질 $(\mathrm{Ni})$ 의 그것 $(776 \mathrm{Hv})$ 를 능가하고 있음을 알 수 있다. 그러나, $\mathrm{CuA}$ $10 \mathrm{NiA}$ 의 경우는 $\mathrm{Cu}$ 와 $\mathrm{Ni}$ 상 모두 비정질이므로, $\mathrm{NiA}$ 첨가의 영향으로 인해 $\mathrm{Cu}$ 의 경도가 무시할 정

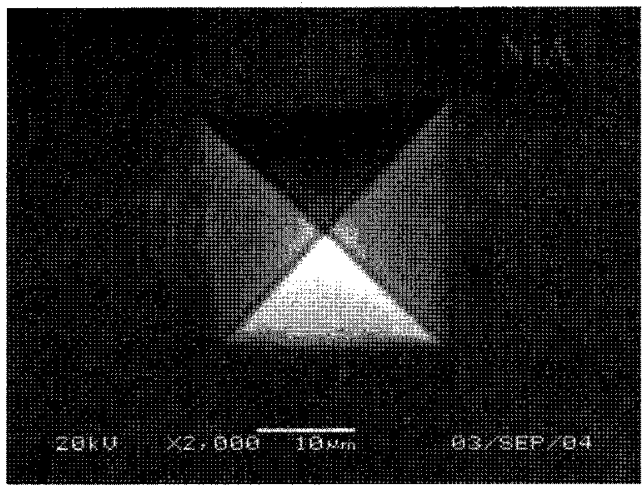

(a) Ni-based metallic glasses phases

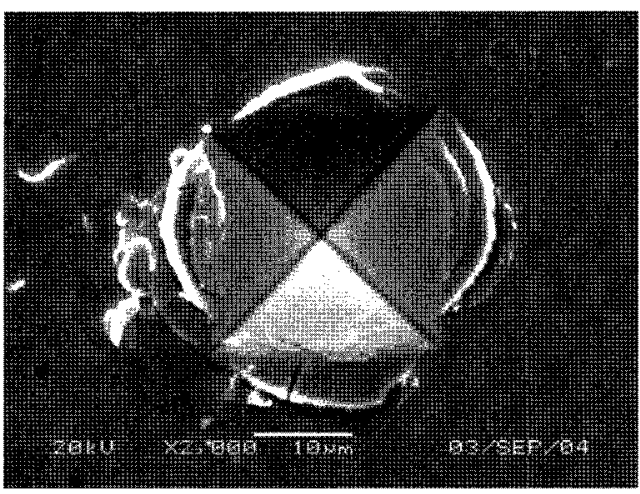

(b) Cu-based nanocrystallities glasses phases

Fig. 5. Microstructures of MG matrix composites after hardness test.

도인 약 $1.3 \%$ 증가함을 나타내고 있다.

그림 5 는 $\mathrm{Cu}$ 결정이 $\mathrm{Ni}$ 비정질 기지위에 분산된 $\mathrm{NiA} / 10 \mathrm{CuA}$ 복합재를 비커스 경도기를 이용하여 압 입한 후 관찰한 미세조직이다. Ni계 비정질 기지 (a) 는 전형적인 비정질상의 특성을 나타내는 전단을 보 이고 있으며 이에 반해 나노결정화된 $\mathrm{Cu}$ 계 결정질상

Table 2. Mechanical properties of monolithic BMG and BMG matrix composites

\begin{tabular}{|c|c|c|c|c|c|}
\hline \multirow{2}{*}{\multicolumn{2}{|c|}{ Properties }} & \multicolumn{2}{|c|}{ Cu-based } & \multicolumn{2}{|c|}{ Ni-based } \\
\hline & & $\begin{array}{c}\text { Monolithic } \\
\text { MG }\end{array}$ & $\begin{array}{l}\text { MG matrix } \\
\text { composite }\end{array}$ & $\begin{array}{c}\text { Monolithic } \\
\text { MG }\end{array}$ & $\begin{array}{c}\text { MG matrix } \\
\text { composite }\end{array}$ \\
\hline $\mathrm{De}$ & $\left(\mathrm{g} / \mathrm{cm}^{3}\right)$ & 7.24 & 7.27 & 7.65 & 7.61 \\
\hline \multirow{2}{*}{ Hardness (Hv) } & Cu-based Phase & 560 (Amor) & 567(Amor) & - & 785 (Cryst) \\
\hline & Ni-based Phase & - & 733(Amor) & 734(Amor) & 776(Amor) \\
\hline
\end{tabular}




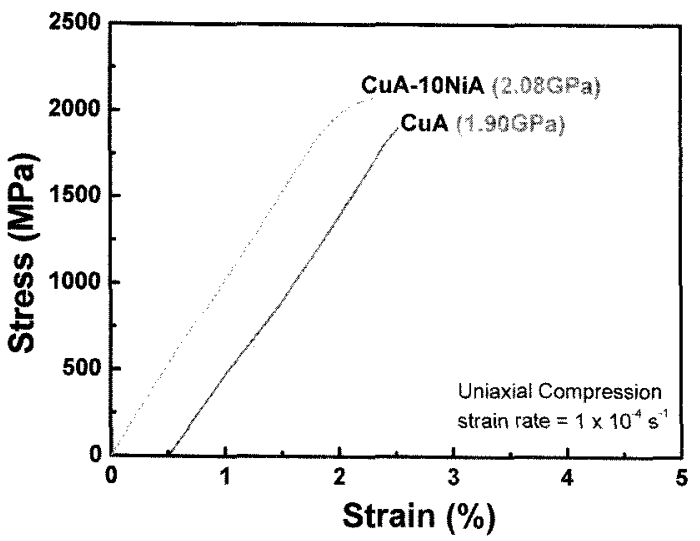

(a) Cu-based monolitic MG and MG matrix composite

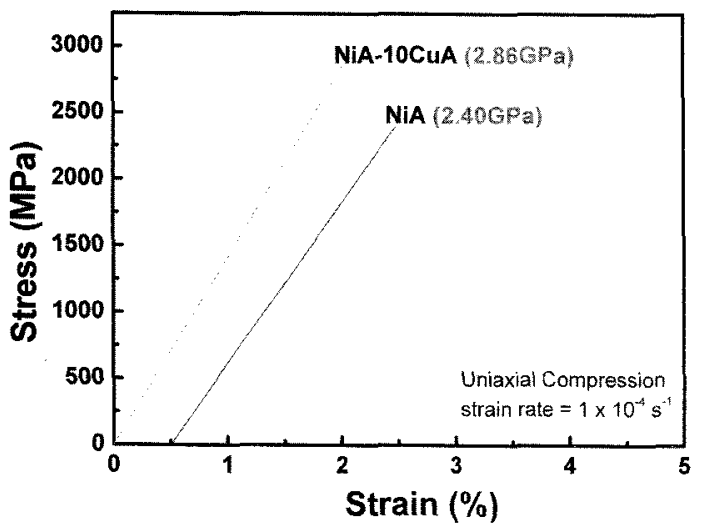

(b) Ni-based moulitic $\mathrm{MG}$ and $\mathrm{MG}$ matrix composite

Fig. 6. Compressive test results of monolithic BMG and MG matrix composites.

은 약간의 전단띠와 동시에 압흔 끝부분에 크랙이 발 생하였음을 알 수 있다.

그림 6은 고화성형된 단일 비정질 소결체 및 비정 질 복합재의 기계적인 특성을 알아보기 위해 압축강 도시험에 의해 얻어진 응력대 연신율 곡선을 보여주 고 있다. 단일 $\mathrm{Cu}$ 계 $(1.90 \mathrm{GPa})$ 및 $\mathrm{Ni}$ 계 $(2.40 \mathrm{GPa})$ 비정질 소결체에 비해 $10 \% \mathrm{NiA}$ 및 $10 \% \mathrm{CuA}$ 를 각각 첨가한 $\mathrm{Cu}$ 계 $(2.08 \mathrm{GPa})$ 및 $\mathrm{Ni}$ 계 $(2.86 \mathrm{GPa})$ 비정질 복합재의 압축강도가 증가함을 알 수 있었다. 이때 각각의 강도의 증가량은 약 $10 \%$ 및 $20 \%$ 정도이다. $10 \% \mathrm{~N}$ 계를 첨가한 $\mathrm{Cu}$ 계 비정질 복합재의 경우 $\mathrm{Cu}$ 계 비정질 기지 내에 더 강한 $\mathrm{Ni}$ 계 비정질 상이 균 일하게 분포되었기 때문이고 $10 \% \mathrm{Cu}$ 계를 첨가한 $\mathrm{Ni}$ 계 비정질 복합재의 경우 압축강도 증가는 Ni계 비 정질 기지 내에 $\mathrm{Cu}$ 계 나노결정질상이 형성되었기 때
문이라 판단된다.

한편, 단일 $\mathrm{Cu}$ 계 및 $\mathrm{Ni}$ 계 비정질 소결체와 $10 \%$ $\mathrm{CuA}$ 를 첨가한 $\mathrm{Cu}$ 계 비정질 복합재에서는 연신 없이 파단이 일어났으나, $10 \% \mathrm{NiA}$ 를 첨가한 $\mathrm{Cu}$ 계 비정 질 복합재의 경우 미세하지만 약간의 연신이 나타났 음을 알 수 있다. 전반적으로 연신의 정도는 작지만, 커다란 강도의 감소를 수반하지 않고 나티나는 연신 의 거동은, 고강도 고인성 비정질/비정질 복합재의 제 조가 추가적인 연구를 통하여 가능하리라 예상할 수 있다. 이때 고려되어야 할 요소로서는 기지재와 강화 재의 입도분포, 혼합률, SPS공정 등의 최적화를 들 수 있을 것이다.

\section{4. 결 론}

기존에 시도된 바 없는 비정질/비정질 복합재료를 가스 분무법 및 SPS 공정을 이용하여 제조하였다. 이때 기지재 및 강화재로 쓰인 각각의 비정질 분말 조성은 $\mathrm{Cu}_{54} \mathrm{Ni}_{6} \mathrm{Zr}_{22} \mathrm{Ti}_{18}(\mathrm{CuA})$ 및 $\mathrm{Ni}_{59} \mathrm{Zr}_{15} \mathrm{Ti}_{13} \mathrm{Nb}_{7} \mathrm{Si}_{3}$ $\mathrm{Sn}_{2} \mathrm{Al}(\mathrm{NiA})$ 이었으며, 복합재의 조성은 $\mathrm{CuA} / 10 \mathrm{NiA}$, 및 $\mathrm{NiA} / 10 \mathrm{CuA}$ 이었다. 두 비정질 분말의 열적 특성 차이를 이용하여 SPS한 결과 $\mathrm{NiA} / 10 \mathrm{CuA}$ 는 $\mathrm{Ni}$ 계 비정질기지에 $\mathrm{Cu}$ 계 나노결정상이 분산되었고, $\mathrm{CuA}$ $10 \mathrm{NiA}$ 의 경우 $\mathrm{Cu}$ 계 비정질에 $\mathrm{Ni}$ 계 비정질이 강화 상으로 분포되는 미세조직을 형성하였다.

$\mathrm{Cu}$ 계 및 $\mathrm{Ni}$ 계 단일 비정질 소결체에 비해 $10 \% \mathrm{Ni}$ 계 및 $\mathrm{Cu}$ 계를 첨가한 비정질 복합재의 기계적 특성이 현저히 증가 되었다. 이는 $\mathrm{Cu}$ 비정질 상보다 더 강한 제2상의 $\mathrm{Ni}$ 비정질상의 균일한 존재와 $\mathrm{Cu}$ 계 나노결정 질상의 균일한 분포에 기인한 것으로 판단된다.

\section{참고문헌}

1. G. Shao: Intermetallics, 11 (2003) 313.

2. A. Inoue: Acta Mater., 48 (2000) 279.

3. W. B. Kim, B. J. Ye and S. Yi: Meta.\& Mater. Interna., 10(1) (2004) 1.

4. B. Clausen, S.-Y. Lee, E. Ustundag, C. C. Aydiner, R. D. Conner and M. A. M, Bourke: Scripta Mater., 49 (2003) 123.

5. G. He, J. Eckert and W. Loeser: Acta Mater., 51 (2003) 1621.

6. C. Fan, R. T. Ott and T. C. Hunfnagel: Appl. Phys. Lett., 81 (2002) 1020. 
7. J. K. Lee, H. J. Kim, M. Yamasaki, Y. Kawamura and J. C. Bae: Mater. Sci. Forum, 475-479 (2005) 3419.

8. H. Kato, K. Yubuta, D. V. Louzguine, A. Inoue and H. S. Kim: Scripta Mater., 51 (2004) 577.
9. Y. Kwamura, H. Kato, A. Inoue and T. Masumoto Appl. Phys. Lett., 67 (1995) 2008.

10. D. J. Sordelet, E. Rozhkova, P. Huang and M. C-Dahl borg: J. Mater. Res., 17 (2002) 186. 